\title{
The effect of anti-inflammatory and anti-oxidant diet on immediate and late-phase cutaneous allergic reactions in healthy dogs
}

\author{
Frane Banović ${ }^{1}$, Amanda Blubaugh${ }^{1}$, Tara Denley ${ }^{1}$, and Nikša Lemo ${ }^{2 *}$ \\ ${ }^{I}$ Department of Small Animal Medicine and Surgery, College of Veterinary Medicine, University of Georgia, \\ Athens, GA, USA \\ ${ }^{2}$ Clinic for Internal Diseases, Faculty of Veterinary Medicine, University of Zagreb, Zagreb, Croatia
}

BANOVIĆ, F., A. BLUBAUGH, T. DENLEY, N. LEMO: The effect of antiinflammatory and anti-oxidant diet on immediate and late-phase cutaneous allergic reactions in healthy dogs. Vet. arhiv 89, 641-652, 2019.

\section{ABSTRACT}

Canine atopic dermatitis (AD) is a highly pruritic and inflammatory skin disease that affects $10-15 \%$ of the canine population. The goal of nutritional management for canine AD is to inhibit the inflammatory response, stabilize the skin barrier and support skin and coat health. A new veterinary-exclusive pet food, Hill's Derm Defense (HDD) diet, has been designed for skin and coat health benefits as well as immune modulation in canine AD. This study aimed to evaluate the effect of administrering an oral HDD diet for 6 weeks in suppressing histamine, compound 48/80 and anticanine IgE antibody-induced global wheal scores (GWS) and late phase reactions (LPR) in nine healthy dogs. On days -10 (baseline), 25 and 46 (3 and 6 weeks of only HDD diet treatment) and day 60 (return to baseline), intradermal injections of histamine, anticanine IgE and compound $48 / 80$ were performed on the right lateral side of the thorax in all the dogs. None of the dogs showed any side effects during the study and the HDD diet was well tolerated by all the dogs. There was no significant reduction in histamine, anticanine IgE and compound 48/80 GWS and LPRs with the HDD diet treatment compared to baseline (day -10) and return to baseline (day 60). This research suggests that HDD diet does not exert inhibitory and anti-inflammatory effects on histamine, anticanine IgE- and compound 48/80-mediated skin reactions in healthy dogs. Future studies should assess the clinical efficacy of the HDD diet in controlled clinical trials of dogs with AD.

Key words: diet; intradermal injections; histamine; anticanine IgE; compound 48/80

\section{Introduction}

Canine atopic dermatitis (AD) is a highly pruritic and inflammatory skin disease that affects $10-15 \%$ of the canine population (OLIVRY et al., 2015). Treatment of severe and chronic canine AD cases can be challenging, and current guidelines highlight the need

\footnotetext{
*Corresponding author:
}

Prof Nikša Lemo, dipl. ECVD, DVM, PhD., Clinic for Internal diseases, Faculty of Veterinary Medicine, University of Zagreb, Heinzelova 55, 10000 Zagreb, Croatia, E-mail: nlemo@vef.hr, 
for an integrated treatment approach (OLIVRY et al., 2015). In many cases, systemic immunosuppressants such as glucocorticoids, cyclosporine and oclacitinib are used for long-term control of refractory patients with recurrent flares (OLIVRY et al., 2015).

The goal of nutritional management for canine AD is to inhibit the inflammatory response, stabilize the skin barrier and support skin and coat health (OLIVRY et al., 2015). New veterinary-exclusive pet food for dogs with allergic skin disease (Hill's Prescription Diet $^{\circledR}$ Derm Defense ${ }^{\mathrm{TM}}$ Canine dry food; (Hill's Pet Nutrition Inc., Topeka, KS, USA) has been released onto the pet food market (WERNIMONT et al., 2018). The Hill's Derm Defense (HDD) diet contains a proprietary blend of whole egg, antioxidants and sources of polyphenols. This combination of ingredients is claimed to have antioxidant activity, help modulate the immune response to allergens, stabilize mast cells and decrease histamine and cytokine release (WERNIMONT et al., 2018). A recent open-label pilot study reported reduced scratching in six atopic dogs after HDD diet was given for 4-8 weeks, however, concurrent anti-inflammatory drugs for control of AD were administered during the study (WERNIMONT et al., 2018). To the best of authors' knowledge, there are no studies published evaluating the anti-inflammatory or mast cell stabilizing effect of an HDD diet in healthy dogs or dogs affected with AD as a stand-alone treatment.

Intradermal injections of anticanine IgE antibodies (PUCHEU-HASTON et al., 2006; BIZIKOVA et al., 2010; MURPHY and OLIVRY, 2015; BLUBAUGH et al., 2018), compound 48/80 (MASON and LLOYD, 1996; BÄUMER et al., 2017) and histamine (BARBET and HALLIWELL, 1989; GINEL et al., 2007; BIZIKOVA et al., 2010; BLUBAUGH et al., 2018) induce allergic cutaneous reactions in healthy dogs and are used as a screening model for studying the anti-inflammatory effect of anti-allergic drugs before entering clinical trials. Furthermore, the inhibition of the wheal and flare response to histamine and anticanine $\operatorname{IgE}$ is a traditional pharmacodynamic tool to measure the immunomodulatory drug effect on the intradermal testing in dogs (BIZIKOVA et al., 2008; BIZIKOVA et al., 2010; TEMIZEL et al., 2011; MURPHY and OLIVRY, 2015). Intradermal testing and allergen-specific IgE serology (ASIS) are both adequate to identify the offending allergens in canine $\mathrm{AD}$, and serve as the basis to formulate allergenspecific immunotherapy (OLIVRY et al., 2015). To the authors' knowledge, the inhibitory influence of an HDD diet on intradermal skin testing in dogs has not been evaluated, and it is uncertain whether the results of intradermal testing are reliable in dogs fed the HDD diet, and whether there should be a withdrawal time for the diet before the testing is performed.

The primary goals of this study were to determine the immunomodulatory potential of the HDD diet on immediate and late-phase cutaneous allergic reactions in healthy dogs, and to establish an appropriate withdrawal time from this diet prior to the intradermal testing method. 
F. Banović et al.: The effect of anti-inflammatory and anti-oxidant diet on cutaneous allergic reactions

\section{Materials and methods}

Diet, chemicals and reagents. The Hill's Prescription Diet Derm Defense canine dry food was purchased from the manufacturer. Anticanine IgE was purchased from Bio-Rad, Hercules, CA, USA. Compound 48/80, phosphate buffered saline (PBS) and histamine diphosphate salt were obtained from Sigma-Aldrich, St Louis, MO, USA.

Animals. The study was approved beforehand by our Institutional Animal Care and Use Committee. Nine healthy adult, male-neutered, purpose-bred laboratory Beagles (age 2-3 years), with no previous history of disease were housed in a university setting under standard conditions $\left(20-22^{\circ} \mathrm{C}, 12 \mathrm{hr}\right.$ light/dark cycle, water ad libitum, food twice daily). The sample size was determined to be sufficient to provide $90 \%$ ability to detect a $50 \%$ difference between two groups of values (baseline/return to baseline vs. HDD diet) with a standard deviation of $30 \%$ at $\mathrm{P}=0.05$ (http://powerandsamplesize.com/Calculators/). The dogs had not received any medications for at least 10 weeks prior to enrolment. All dogs were examined by the investigators and confirmed healthy and free of any dermatological or systemic disease five days before the first study day.

Experimental protocol. We evaluated the effect of oral HDD diet for 6 weeks in suppressing histamine, compound 48/80 and anticanine IgE antibody-mediated wheal and flare reaction, as well as late phase reactions (LPRs) in nine healthy dogs. The study was designed as an open-label study where each dog served as its own control (Fig. 1). A baseline evaluation of intradermal injections was obtained 10 days prior to initiating the HDD diet (day -10) and a return to baseline was performed 10 days after the HDD diet had been completely discontinued (day 60). All dogs were slowly transitioned from the regular diet fed (Purina Pro Plan Small Bites Lamb and Rice, Nestlé Purina Petcare, St. Louis, MO, USA) over 4 days and then exclusively fed the HDD diet for 6 weeks during the study. After 6 weeks of HDD diet, all dogs were transitioned back to their original diet (Purina Pro Plan Small Bites Lamb and Rice) over 4 days and then continued long-term with the Purina Pro Plan Small Bites Lamb and Rice diet. Return to baseline evaluation was performed 10 days after complete diet transition (day 60).

Intradermal challenge. A large (about $15 \mathrm{~cm} \times 10 \mathrm{~cm}$ ) area for injection of the substances was clipped on the right lateral thoracic region; all injection site clippings were performed at least 48 hours prior to each injection, to avoid any occurrence of localized skin reaction or irritation in concurrence with the administration and evaluation of the substances.

Dogs were sedated intravenously using medetomidine (Domitor, Pfizer, Exton, PA). On days -10 (baseline), 25 and 47 (3 and 6 weeks of only HDD diet) and 60 (return to baseline), one of the investigators (FB) performed intradermal injections of 0.05 $\mathrm{mL}$ phosphate-buffered saline (negative control), histamine phosphate $(0.1 \mathrm{mg} / \mathrm{mL})$, anticanine $\operatorname{IgE}$ polyclonal antibodies $(0.08 \mathrm{mg} / \mathrm{mL})$ and compound $48 / 80(0.2 \mathrm{mg} / \mathrm{mL})$ 
on the right lateral side of the thorax. The order of injections was randomized using statistical computer software (Prism 8.0; GraphPad Softwares, La Jolla, CA, USA) and the investigator (FB) was blinded during intradermal injection evaluations. The concentrations of the substances were chosen from the established intradermal-induced cutaneous allergic reaction studies in dogs (BARBET and HALLIWELL, 1989; MASON and LLOYD, 1996; DEBOER and COOLEY, 2000; PUCHEU-HASTON et al., 2006; GINEL et al., 2007; BIZIKOVA et al., 2008; BIZIKOVA et al., 2010; TEMIZEL et al., 2011; MURPHY and OLIVRY, 2015; BÄUMER et al., 2017; BLUBAUGH et al., 2018).

Clinical evaluation. Twenty minutes after each injection, the extent and severity of the wheals were assessed by the same investigator (FB) who performed the injections. The global wheal score (GWS) was calculated from all measurements as previously reported (BARBET and HALLIWELL, 1989; MASON and LLOYD, 1996; DEBOER and COOLEY, 2000; PUCHEU-HASTON et al., 2006; GINEL et al., 2007; BIZIKOVA et al., 2008; BIZIKOVA et al., 2010; TEMIZEL et al., 2011; MURPHY and OLIVRY, 2015; BÄUMER et al., 2017; BLUBAUGH et al., 2018): GWS $=\mathrm{D} \times \mathrm{E} \times \mathrm{F}$ (the average diameter (D) in orthogonal directions was measured in millimeters; with erythema (E) and firmness (F). Six hours following all intradermal injections, the global LPR score (GLS) was determined as follows: GLS $=\mathrm{E} \times \mathrm{I}$ (erythema (E); the degree of skin induration (I)).

Statistical analysis. The results of the clinical evaluation (GWS and GLS) between different compounds were compared within each study time point, using a non-parametric Friedman test (GraphPad Prism 8.0, San Diego, CA, USA). The clinical values (GWS and GLS) obtained before treatment (baseline; days -10), during the HDD diet treatment (days 25 and 47), and after discontinuation of the HDD diet (day 60) were compared using nonparametric repeated measures one-way ANOVA (GraphPad Prism 8.0). The level of significance was set at $\mathrm{P}<0.05$.

\section{Results}

None of the dogs showed any side effects during the study and the HDD diet was well tolerated by all dogs.

Global wheal scores. Intradermal injection of histamine, anticanine IgE and compound 48/80 resulted in positive wheal and erythema reactions on the right thoracic side in all nine dogs before (baseline, day -10) and after (return to baseline, day 60) HDD diet treatment (Fig. 2). There were no wheal and flare reactions observed after the intradermal injections of phosphate-buffered saline (control). Global wheal scores at $30 \mathrm{~min}$ post-injection of each substance significantly increased at all concentrations compared to the control on days -10 (baseline), 25 and 47 (3 and 6 weeks of HDD diet alone), 60 (return to baseline) (Fig. 3; Friedman test for all time points, $\mathrm{P} \leq 0.05$ ) 
F. Banović et al.: The effect of anti-inflammatory and anti-oxidant diet on cutaneous allergic reactions

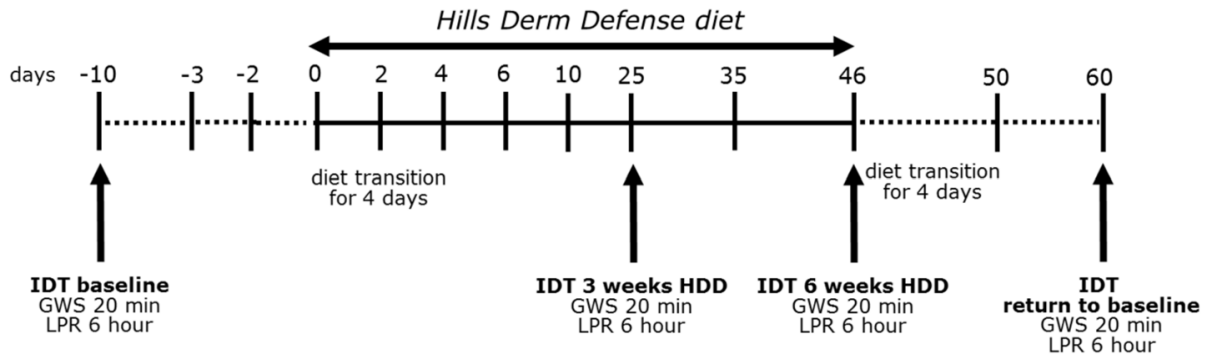

Fig. 1. Experimental study design
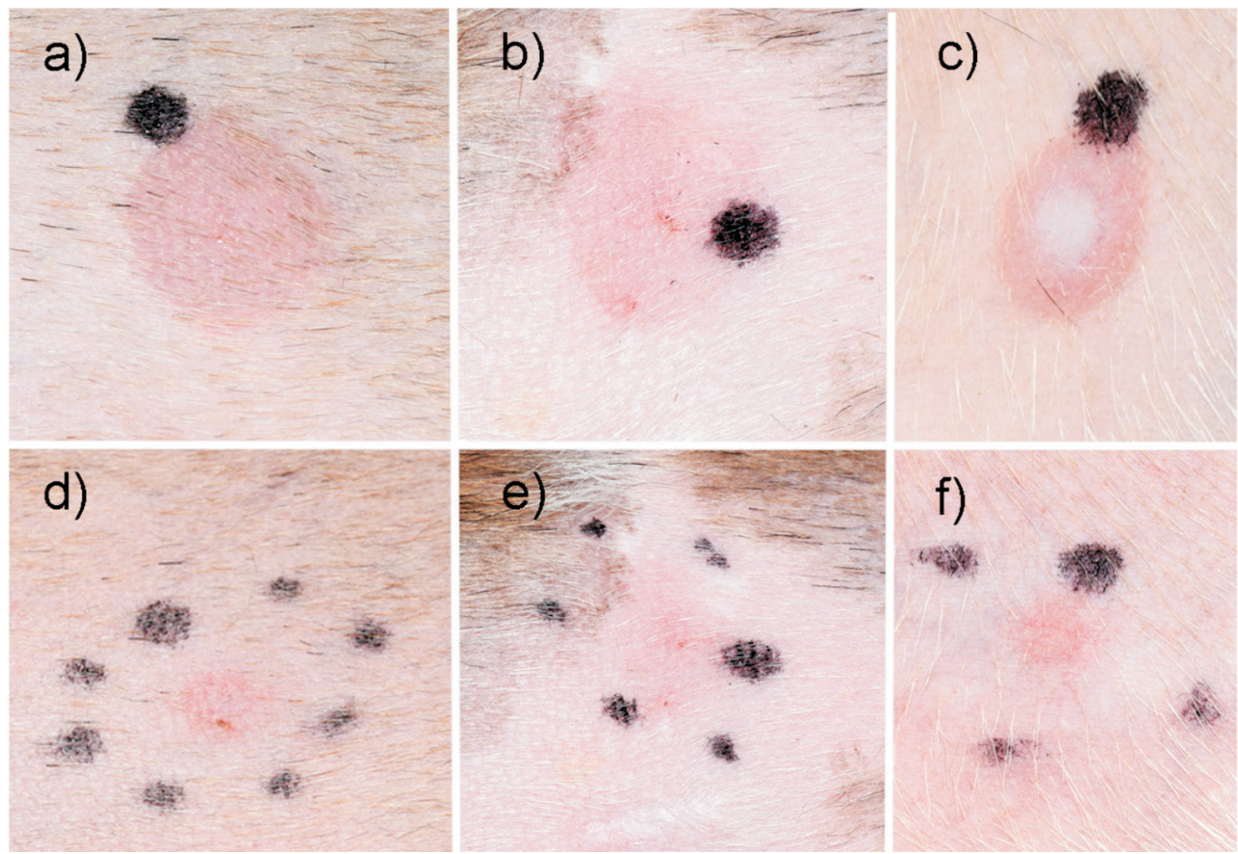

Fig. 2. Clinical images of wheal and flare responses of tested substances. Intradermal injections of histamine (a), anticanine-IgE (b) and compound 48/80 (c) resulted in a positive wheal and erythema reactions in all dogs at baseline (day -10) and the return to baseline time point (day 60). Late phase reactions were observed at 6 hours post-injection of histamine (d), anticanine-IgE (e) and compound $48 / 80$ (f). 
F. Banović et al.: The effect of anti-inflammatory and anti-oxidant diet on cutaneous allergic reactions

a)

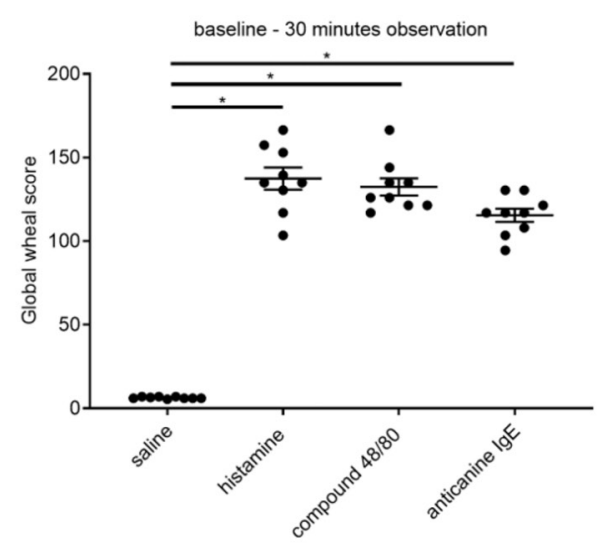

c)

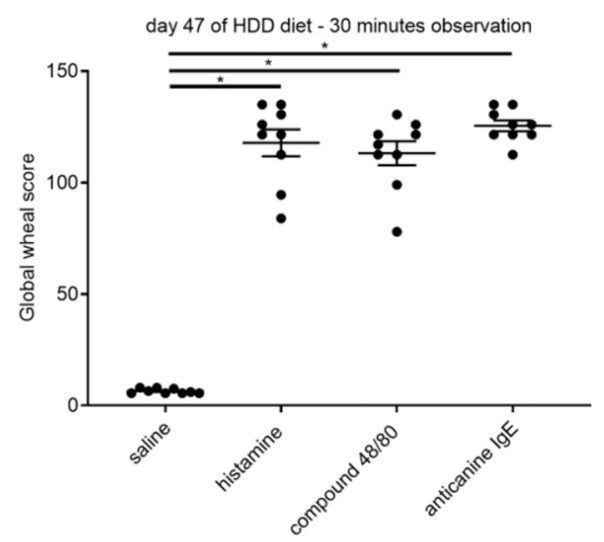

b)
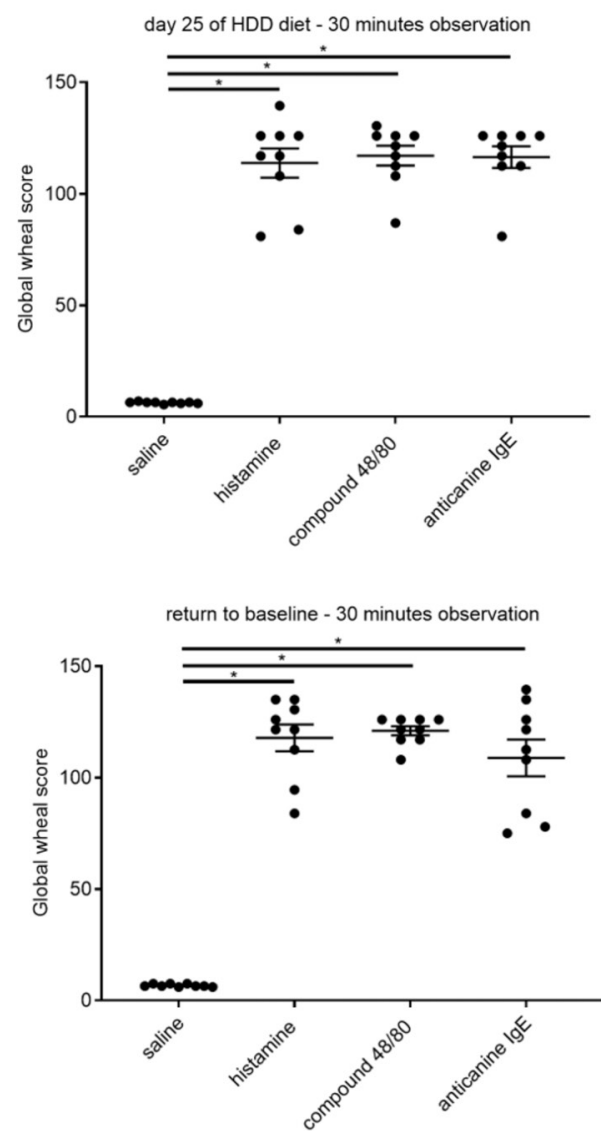

Fig. 3. Global wheal scores at $30 \mathrm{~min}$ post-injection of each substance significantly increased at all concentrations compared to control on days -10 (baseline), 25 and 47 (3 and 6 weeks of only HDD diet), 60 (return to baseline) (Fig. 2; Friedman test for all time points, $\mathrm{P} \leq 0.05$ )

There was no significant reduction in histamine, anticanine IgE and compound 48/80 GWS with the HDD diet treatment (Fig. 4a,b,c; one-way ANOVA) compared to baseline (day -10) and return to baseline (day 60). 
F. Banović et al.: The effect of anti-inflammatory and anti-oxidant diet on cutaneous allergic reactions

a)

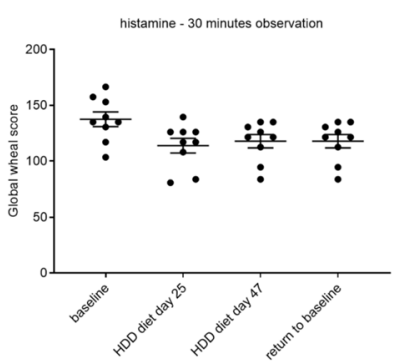

b)

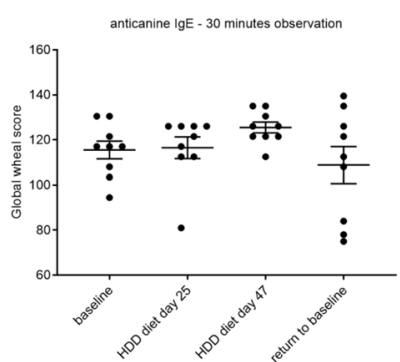

c)

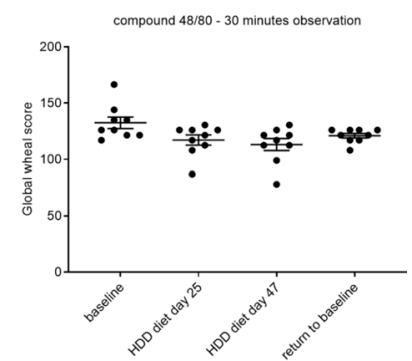

Fig. 4. Global wheal scores (GWS) of histamine, anticanine-IgE and compound 48/80 during the HDD diet study. There was no significant reduction in histamine (a), anticanine-IgE (b) and compound 48/80 (c) GWS with HDD diet treatment on day 25 and day 47 compared to baseline (day -10) and return to baseline (day 60); one-way ANOVA.

a)

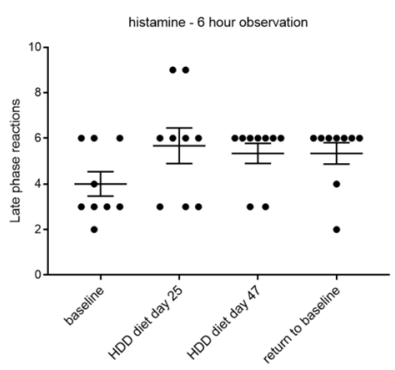

b)

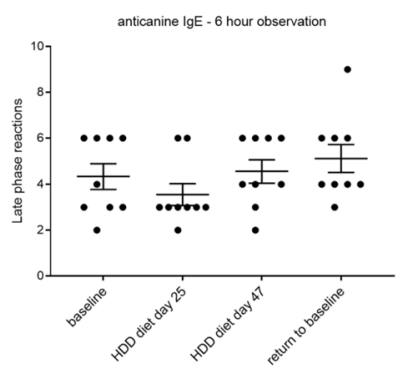

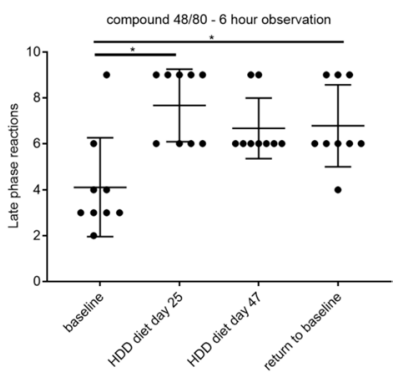

Fig. 5. Late phase reactions (LPRs) of histamine, anticanine-IgE and compound 48/80 during the HDD diet study. No statistical significance for histamine and anticanine IgE LPRs was observed using the one-way ANOVA test between HDD diet treatment and controls. A significant increase in compound 48/80 LPRs was observed between baseline and during HDD treatment on day 25 well as at the return to baseline time point.

Late phase reactions. No statistical significance for histamine (baseline versus day $25, \mathrm{P}=0.66$; baseline versus day $47, \mathrm{P}=0.66$; return to baseline versus day $25, \mathrm{P}=0.66$; return to baseline versus day $47, \mathrm{P}=0.66$ ) and anticanine $\operatorname{IgE}$ (baseline versus day $25, \mathrm{P}$ $=0.66$; baseline versus day $47, \mathrm{P}=0.66$; return to baseline versus day $25, \mathrm{P}=0.66$; return to baseline versus day $47, \mathrm{P}=0.66) \mathrm{LPRs}$ was observed using the one-way ANOVA test between the HDD diet treatment and controls (Fig. 2 d,e,f; Fig. 4). Furthermore, there were no positive LPRs observed after the intradermal injections of phosphate-buffered saline (control). A significant increase in compound 48/80 LPRs was observed between baseline and on HDD treatment day 25 (baseline versus day 25, $\mathrm{P}=0.66$ ) as well as the return to baseline time point (Fig. 5, baseline versus return to baseline, $\mathrm{P}=0.66$ ). 
F. Banović et al.: The effect of anti-inflammatory and anti-oxidant diet on cutaneous allergic reactions

\section{Discussion}

This study demonstrates that HDD diet does not exert any inhibitory effects on immediate and late-phase cutaneous allergic reactions induced by intradermal injections of histamine, anticanine IgE and compound 48/80 in healthy dogs. This finding is unlikely to be related to a lack of substance-induced cutaneous inflammation or the concentrations of tested substances. Positive wheal reactions were observed in all dogs included in this study at baseline and return to baseline. Furthermore, the injected substance concentrations in our study were equivalent to those used in dogs for investigations of the anti-inflammatory effect of anti-allergic drugs.

The HDD diet is designed to contain whole egg, antioxidants and sources of polyphenols as ingredients chosen for their ability to improve skin barrier function and lower inflammation canine AD (WERNIMONT et al., 2018). In 2014, Plevnik et al. reported low plasma vitamin E levels in dogs with AD (PLEVNIK et al., 2013) and supplementation with $8.1 \mathrm{IU} / \mathrm{kg}$ vitamin $\mathrm{E}$ once daily orally reduced the clinical scores in AD dogs (PLEVNIK et al., 2014). Based on the manufacturer's statement, the HDD diet contains vitamin $\mathrm{E}$ in excess of the above-recommended amount and also contains other anti-oxidant sources, including vitamin $\mathrm{C}$, and green tea as a source of catechins and lipoic acid. Immunoglobulin-E mediated reactions, induced by intradermal injection of anticanine $\mathrm{IgE}$ antibodies, are characterized by a wheal and flare response which histologically resembles changes seen in naturally occurring allergic dermatitis in dogs (PUCHEU-HASTON et al., 2006). Intradermal injection of anticanine IgE in normal dogs triggers a cascade of biochemical signal transduction events, resulting in immediate 15-30 min wheal and flare responses (GWS) and delayed LPRs (PUCHEU-HASTON et al., 2006). Histologically, there is a rapid biphasic influx of inflammatory cells, with an early influx of predominantly activated eosinophils, mast cells and neutrophils, whereas mainly T-lymphocytes and dendritic cells predominate at 24h (PUCHEU-HASTON et al., 2006). This screening model is used for studying the anti-inflammatory effect and the effect on mast cell stabilization of anti-allergic drugs before entering clinical trials (PUCHEU-HASTON et al., 2006; BIZIKOVA et al., 2008; BIZIKOVA et al., 2010; MURPHY and OLIVRY, 2015; BLUBAUGH et al., 2018). The injections of anticanine IgE produced strong wheal and flare responses in all the dogs used in our study. However, there was no significant inhibitory effect from the HDD diet on the immediate and latephase anticanine IgE induced responses in our healthy dogs.

Histamine is an important mediator of immediate allergic reactions in dogs; histamine injections induce congestion and plasma extravasation in the interstitial dermis, and cause the typical macroscopic wheal and flare reaction (THURMOND et al., 2008). Intradermal injections of histamine have been used to assess the pharmacodynamic inhibitory effect of antihistamines and other anti-inflammatory drugs in dogs (BARBET and HALLIWELL, 
1989; GINEL et al., 2007; BIZIKOVA et al., 2008; BIZIKOVA et al., 2010; BLUBAUGH et al., 2018). Furthermore, the effect of drugs on immediate histamine-associated wheal and flare reactions is important for clinicians to evaluate the withdrawal time in canine $\mathrm{AD}$ patients, for intradermal allergic testing and allergen-specific immunotherapy. To the authors' knowledge, this is the first report evaluating the effect of an immunomodulatory diet on histamine-induced wheal and flare reactions in dogs. In the present study, there was no significant inhibition of histamine-induced GWS and LPRs in healthy dogs after 6 weeks of the HDD diet.

The Mas-related G-protein-coupled receptors (Mrgprs), implicated in allergic inflammation and itch, are expressed on the peripheral terminals of sensory neurons and mast cells (SUBRAMANIAN et al., 2016). Compound 48/80 induces mast cell degranulation by activating Mas-related G protein-coupled receptor X2 (MRGPRX2) on mast cells in humans and dogs (HAITINA et al., 2009; SUBRAMANIAN et al., 2016), and therefore is widely used for non-IgE dependent stimulation of mast cells. Similar to anticanine IgE allergic reactions, intradermal injections of compound 48/80 in healthy dogs elicit a rapid biphasic influx of inflammatory cells, with an early influx of predominantly activated eosinophils and mast cells, whereas mainly T-lymphocytes, neutrophils and dendritic cells predominate at 24h (MASON and LLOYD, 1996). The intradermal injection of compound $48 / 80$ has been studied as a test system to evaluate the anti-inflammatory effect of topical glucocorticoids in an immediate type hypersensitivity canine model. It was shown that topically applied glucocorticoids inhibited the "reaction area" induced by compound 48/80 in healthy dogs (DEBOER and COOLEY, 2000; BÄUMER et al., 2017). Although compound $48 / 80$ provoked distinct immediate wheal and flare reactions, as well as LPRs, in our healthy dogs, the HDD diet showed no inhibitory effect in the dogs tested.

In conclusion, the experiments described here demonstrate that feeding the HDD diet for 6 weeks did not exert inhibitory and anti-inflammatory effects on histamine, anticanine IgE- and compound 48/80-mediated skin reactions in healthy dogs. The main limitation of this study is the small number of healthy dogs, so future controlled studies should assess the clinical efficacy and the effect on intradermal testings in larger number of dogs with $\mathrm{AD}$.

\section{Acknowledgements}

The authors express their sincere thanks to Thomas Cambell for his help with sedation of dogs during the study. 
F. Banović et al.: The effect of anti-inflammatory and anti-oxidant diet on cutaneous allergic reactions

\section{References}

BARBET, J. L., R. E. W. HALLIWELL (1989): Duration of inhibition of immediate skin test reactivity by hydroxyzine hydrochloride in dogs. J. Am. Vet. Med. Assoc. 11, 1565-1569.

BÄUMER, W., K. ROSSBACH, B. H. SCHMIDT (2017): The selective glucocorticoid receptor agonist mapracorat displays a favourable safety-efficacy ratio for the topical treatment of inflammatory skin diseases in dogs. Vet. Dermatol. 28, 46-e11.

DOI: $10.1002 / 9781119278368 . \operatorname{ch} 3.1$

BIZIKOVA, P., M. G. PAPICH, T. OLIVRY (2008): Hydroxyzine and cetirizine pharmacokinetics and pharmacodynamics after oral and intravenous administration of hydroxyzine to healthy dogs. Vet. Dermatol. 19, 348-357.

DOI: 10.1111/j.1365-3164.2008.00697.x

BIZIKOVA, P., K. E LINDER, J. PAPS, T. OLIVRY (2010): Effect of a novel topical diester glucocorticoid spray on immediate- and late-phase cutaneous allergic reactions in Maltesebeagle atopic dogs: a placebo-controlled study. Vet. Dermatol. 21, 70-79.

DOI: 10.1111/j.1365-3164.2009.00782.x

BLUBAUGH, A., D. RISSI, D. ELDER, T. DENLEY, S. EGUILUZ-HERNANDEZ, F. BANOVIC (2018): The anti-inflammatory effect of topical tofacitinib on immediate and late-phase cutaneous allergic reactions in dogs: a placebo-controlled pilot study. Vet. Dermatol. 29, 250e93.

DOI: $10.1111 /$ vde. 12532

DEBOER, D. J., A. J. COOLEY (2000): Use of induced cutaneous immediate type hypersensitivity reactions to evaluate anti-inflammatory effects of triamcinolone topical solution in three dogs. Vet. Dermatol. 11, 25-33.

DOI: 10.1046/j.1365-3164.2000.00157.x

GINEL, P. J., C. GARRIDO, R. LUCENA (2007): Effects of otic betamethasone on intradermal testing in normal dogs. Vet. Dermatol. 18, 205-210.

DOI: 10.1111/j.1365-3164.2007.00591.x

HAITINA, T., R. FREDRIKSSON, S. M. FOORD, H. B. SCHIÖTH, D. E. GLORIAM (2009): The $\mathrm{G}$ protein-coupled receptor subset of the dog genome is more similar to that in humans than rodents. BMC. Gen. 10, 24.

DOI: $10.1186 / 1471-2164-10-24$

MASON, I., D. LLOYD (1996): Evaluation of compound 48/80 as a skin model of immediate hypersensitivity in the skin of dogs. Vet. Dermatol. 7. 81-83.

DOI: 10.1111/j.1365-3164.1996.tb00230.x

MURPHY, K. M., T. OLIVRY (2015): The influence of Mometamax (mometasone furoate) on intradermal test immediate reactions in atopic dogs. Vet. Dermatol. 26, 31-34.

DOI: $10.1111 /$ vde. 12171 
F. Banović et al.: The effect of anti-inflammatory and anti-oxidant diet on cutaneous allergic reactions

OLIVRY, T., D. J. DEBOER, C. FAVROT, H. A. JACKSON, R. S. MUELLER, T. NUTTALL, P. PRÉLAUD, INTERNATIONAL COMMITTEE ON ALLERGIC DISEASES OF ANIMALS (2015): Treatment of canine atopic dermatitis: 2015 updated guidelines from the International Committee on Allergic Diseases of Animals (ICADA). BMC. Vet. Res. 11, 210.

DOI: $10.1186 / \mathrm{s} 12917-015-0514-6$

PLEVNIK KAPUN, A., J. SALOBIR, A. LEVART, G. TAVČAR KALCHER, A. NEMEC SVETE, T. KOTNIK (2013): Plasma and skin vitamin E concentrations in canine atopic dermatitis. Vet. Q. 33, 2-6.

DOI: $10.1080 / 01652176.2012 .758395$

PLEVNIK KAPUN, A., J. SALOBIR, A. LEVART, G. TAVČAR KALCHER, A. NEMEC SVETE, T. KOTNIK (2014): Vitamin E supplementation in canine atopic dermatitis: improvement of clinical signs and effects on oxidative stress markers. Vet. Rec. 175, 560.

DOI: $10.1136 /$ vr.102547

PUCHEU-HASTON, C. M., D. SHUSTER, T. OLIVRY, P. BRIANCEAU, P. LOCKWOOD, T. McCLANAHAN, R. DE WAAL MALEFYT, J. D. MATTSON, B. HAMMERBERG (2006): A canine model of cutaneous late-phase reactions: prednisolone inhibition of cellular and cytokine responses. Immunology 117, 177-187.

DOI: $10.1111 /$ j.1365-2567.2005.02276.x

SUBRAMANIAN, H., K. GUPTA, H. ALI (2016): Roles of Mas-related G protein-coupled receptor X2 on mast cell-mediated host defense, pseudoallergic drug reactions, and chronic inflammatory diseases. J. Allergy Clin. Immunol. 138, 700-710.

DOI: 10.1016/j.jaci.2016.04.051

TEMIZEL, E. M., H. CIHAN, B. AKHTARDANESH, N. AYTUG (2011): Effect of prednisolone and cetirizine on D. farinae and histamine-induced wheal and flare response in healthy dogs. Tierarztl. Prax. Ausg. K. 39, 25-30.

DOI: $10.1055 / \mathrm{s}-0037-1622566$

THURMOND, R. L., E. W. GELFAND, P. J. DUNFORD (2008): The role of histamine H1 and H4 receptors in allergic inflammation: the search for new antihistamines. Nat. Rev. Drug. Discov. 7, 41-53.

DOI: $10.1038 / \operatorname{nrd} 2465$

WERNIMONT, S. M., R. J. THOMPSON, S. L. MICKELSEN, S. C SMITH, I. C. ALVARENGA, K. L GROSS (2018): Use of accelerometer activity monitors to detect changes in pruritic behaviors: interim clinical data on 6 dogs. Sensors (Basel) 16, 18.

DOI: $10.3390 / \mathrm{s} 18010249$

Received: 12 March 2019

Accepted: 7 June 2019

Vet. arhiv 89 (5), 641-652, 2019 
F. Banović et al.: The effect of anti-inflammatory and anti-oxidant diet on cutaneous allergic reactions

\section{BANOVIĆ, F., A. BLUBAUGH, T. DENLEY, N. LEMO: Učinak protuupalne i antioksidativne prehrane na trenutačnu i kasnu reakciju preosjetljivosti kože u zdravih pasa. Vet. arhiv 89, 641-652, 2019.}

\section{SAŽETAK}

Atopijski dermatitis pasa (AD) jest upalna bolest kože s izrazitim svrbežom koja zahvaća od 10 do 15 $\%$ populacije pasa. Cilj hranidbe kod AD-a pasa jest inhibirati upalni odgovor, stabilizirati kožnu barijeru i zdravlje dlačnog pokrova. Nova, ekskluzivna veterinarska hrana za kućne ljubimce, Hills Derm Defense (HDD), dizajnirana je za dobrobit kože i dlačnog pokrova kao i za imunomodulaciju pri AD-u. Cilj ovoga istraživanja bila je procjena učinka prehrane HDD-om tijekom 6 tjedana u supresiji histamina, sastojka 48/80 i nastanka zadebljanja kože (Global wheal score, GWS) uzrokovanih anti-psećim IgE protutijelima kao i kasne reakcije preosjetljivosti (LPR) u devet zdravih pasa. Histamin, anti-pseći IgE i sastojak 48/80 aplicirani su intradermalno u postranom području prsnoga koša pasa 10. dan od početka pokusa (temeljna vrijednost), 25 ., 46. (3 i 6 tjedana isključivo HDD prehrane) i 60. dan (povratak na početnu vrijednost). Nuspojave nisu utvrđene, a psi su dobro prihvatili HDD prehranu. Nije utvrđeno znakovito sniženje koncentracija histamina, anti-psećeg IgE i sastojka 48/80 GWS i LPRs pasa hranjenih HDD-om u odnosu na početnu vrijednost (10. dan) i povratak na početno stanje (60. dan). Ovo istraživanje pokazuje da HDD prehrana nema inhibicijski i protuupalni učinak na histamin, antipseći IgE i sastojak 48/80 u zdravih pasa. Buduća istraživanja trebala bi ocijeniti klinički učinkovitost HDD prehrane u pasa S AD.

Ključne riječi: prehrana; intradermalna aplikacija; histamin; anti-pseći IgE; sastojak 48/80 